\title{
Performance of Four Anti-Heparin/Platelet Factor 4 Immunoassays for the Diagnosis of Heparin-Induced Thrombocytopenia
}

Jae Hyeon Park, Ji-Eun Kim, Hyun Ju Yoo, Ja-Yoon Gu, Kyou Sup Han, and Hyun Kyung Kim

Department of Laboratory Medicine, Seoul National University College of Medicine, Seoul, Korea

Corresponding author: Hyun Kyung Kim Department of Laboratory Medicine, Seoul National University Hospital, Seoul National University College of Medicine, 101 Daehak-ro, Jongno-gu, Seoul 110-744, Korea Tel: +82-2-2072-0853 Fax: +82-2-747-0359 E-mail: lukekhk@snu.ac.kr
Background: Heparin-induced thrombocytopenia (HIT) is a significant complication of heparin therapy induced by antibodies to heparin/platelet factor 4 (PF4) complexes. We investigated the diagnostic performance of four commercial immunoassays that detect the anti-heparin/PF4 antibody.

Methods: Four different anti-heparin/PF4 antibody assays were performed in 39 patients with suspected HIT: HemosIL AcuStar HIT-IgG, HemosIL AcuStar HIT-total antibody (Ab) (Instrumentation Laboratory, USA), STic Expert HIT (Diagnostica Stago, France), and PF4 Enhanced (Immucor GTI Diagnostics, USA). Patients were diagnosed with HIT when the Chong score was $\geq 5$.

Results: The estimated sensitivity and specificity for diagnosis of HIT were $33.3 \%$ and $80.0 \%$ for AcuStar HIT-IgG, 55.6\% and 53.3\% for AcuStar HIT-total Ab, 100.0\% and 37.9\% for STic Expert HIT, and $33.3 \%$ and $66.7 \%$ for PF4 Enhanced. All specificities significantly increased when $4 \mathrm{Ts}$ scores were included in the diagnosis. The areas under the curves (AUCs) for predicting thrombosis in the AcuStar HIT-IgG, AcuStar HIT-total Ab, and PF4 Enhanced assays were $0.639,0.522$, and 0.681 , respectively. When the results of each assay were analysed along with 4Ts scores, the AUC increased to 0.927 in the AcuStar HIT-IgG assay and 0.944 in the AcuStar HIT-total Ab and PF4 Enhanced assays.

Conclusions: The STic Expert HIT assay had high sensitivity but low specificity for diagnosis of HIT. The performances of the three other immunoassays were comparable to each other. Specificity significantly increased when assay data were combined with 4 Ts scores. Differences in the diagnostic performance of the four immunoassays were not evident, and simultaneous consideration of clinical scoring systems improved performance.

(J Lab Med Qual Assur 2015;37:84-91)

Key Words: Heparin-induced thrombocytopenia, Immunoassay, Diagnostic performance, Thrombosis

Received December 1, 2014, Revision received February 23, 2015, Accepted March 3, 2015

\section{서론}

헤파린유도혈소판감소증(heparin-induced thrombocytopenia, HIT)은 헤파린 치료에 의해 발생할 수 있는 심각 한 합병증으로 헤파린과 platelet factor $4(\mathrm{PF} 4)$ 의 복합체에 대한 자가항체(항-헤파린/PF4 항체)에 의해서 발생한다[1,2]. 이 복합체는 혈소판의 $\mathrm{Fcy}$ 수용체 IIA에 결합 후 혈소판을 활 성화시켜 혈소판미세입자 분비와 함께 혈소판의 응집을 일
으켜 혈소판 감소와 동정맥 혈전을 일으킨다[1]. 항-헤파린/ $\mathrm{PF} 4$ 항체검사는 기능적인 검사로 확진하는데, 방사성 세로토 닌을 사용하는 세로토닌분비검사(serotonin-release assay) 와 방사성 물질을 사용하지 않는 헤파린유도혈소판활성검사 (heparin-induced platelet activation assay)가 있으나 공여 자 혈소판을 사용해야 하며 시행하기 어려워서 주로 면역학적 인 방법을 이용하고 있다[1-3]. 헤파린/PF4 복합체에 대한 다 특이적인 항체 $(\mathrm{IgG} / \mathrm{A} / \mathrm{M})$ 를 모두 검출하는 검사에 비해 $\operatorname{IgG}$ 


\title{
Journal of LABORATORY MEDICINE and QUALITY ASSURANCE
}

\author{
Jae Hyeon Park et al • Performance of Anti-Heparin/PF4 Ab
}

항체만 검출하는 것이 특이도와 양성예측도가 우수하다고 알 려져 있다[2-4]. 임상적인 지표로 $\mathrm{HIT}$ 를 예측하기 위한 점수 체계로는 혈소판감소증(thrombocytopenia), 헤파린 노출에 비한 혈소판 감소의 시기(timing of platelet count fall), 혈전 증과 기타 합병증(thrombosis), 혈소판 감소증의 다른 원인 (thrombocytopenia by other causes)을 점수화하는 '4Ts' 점 수체계가 있으며(Table 1) [5], 혈소판감소증의 발생 시기, 혈 소판감소증의 다른 원인, 헤파린을 중단 후 혈소판감소증 회복 여부와 재투여 시 재발 여부, 혈전증, HIT의 면역검사 및 기능 검사를 점수화하는 Chong 점수가 있다(Table 2) [6]. 현재 두 임상 점수체계 중 어느 쪽을 권장한다는 학계의 지침이 없으 며, Chong 점수에서는 헤파린 중단 후 혈소판감소증 회복 여 부와 재발 여부에 항체검사결과를 포함하여 더 포괄적인 $\mathrm{HIT}$ 진단이 가능하다고 생각된다. HIT로 인한 혈전증을 검출하지 못하면 헤파린 치료를 지속하게 되어 환자에게 혈전이 악화되
는 심각한 합병증을 초래할 수 있으며, HIT를 과잉 진단하게 되면 헤파린 이외의 항응고제 사용이 증가해 출혈 위험이 증가 할 수 있다[7].

국내에는 2013년 6월부터 항-헤파린/PF4 항체검사에 대한 요양급여가 시작되었으며, 현재 상품화된 항-헤파린/PF4 항 체 진단 시약이 여러 회사에서 출시되고 있으나 아직 평가자료 가 없다. 이에 본 연구에서는 흔히 사용하는 상품화된 진단시 약 4 가지를 비교 평가하여, 항-헤파린/PF4 항체 시약에 대한 평가자료를 임상검사실에 제공하고자 한다.

\section{재료 및 방법}

\section{1. 연구대상}

본 연구는 헤파린을 사용한 후 임상적으로 $\mathrm{HIT}$ 가 의심되 어 항-헤파린/PF4 항체검사가 의뢰된 39명을 대상으로 하였

Table 1. The 4Ts scoring system

\begin{tabular}{|c|c|c|c|}
\hline Characteristic & 2 Points & 1 Point & 0 Point \\
\hline Thrombocytopenia & $\begin{array}{l}>50 \% \text { platelet fall } \\
\quad\left(\text { nadir } \geq 20 \times 10^{9} / \mathrm{L}\right)\end{array}$ & $\begin{array}{l}30 \%-50 \% \text { platelet fall or nadir } \\
10-19 \times 10^{9} / \mathrm{L}\end{array}$ & $\begin{array}{l}<30 \% \text { platelet fall } \\
\text { or nadir } \leq 10 \times 10^{9} / \mathrm{L}\end{array}$ \\
\hline $\begin{array}{l}\text { Other cause of } \\
\text { thrombocytopenia }\end{array}$ & None evident & Possible & Definite \\
\hline
\end{tabular}

Pretest probability score: 6-8, high; $4-5$, moderate; $0-3$, low.

Table 2. Chong scoring system

\begin{tabular}{l}
\hline \multicolumn{1}{c}{ Criteria } \\
\hline${\text { Onset of thrombocytopenia }{ }^{*} \text { (or a substantial decrease in platelets, by }>50 \% \text { of baseline) } 4-14 \text { days after starting heparin }}^{\text {Point }}$ \\
Onset of thrombocytopenia outside above time interval \\
Exclusion of other causes of thrombocytopenia \\
Thrombocytopenia resolves after discontinuing heparin \\
Thrombocytopenia recurs on heparin rechallenge \\
Thrombosis associated with thrombocytopenia \\
Laboratory tests \\
Immunoassay positive \\
Functional assays: two-point system \\
Functional assays: non-two-point system \\
\hline
\end{tabular}

*The presence of thrombocytopenia is mandatory. Thrombocytopenia is defined as a platelet count below $150 \times 10^{9} / \mathrm{L}$. If the total point is $>7$, $5-6,3-4$, and $<3$, the diagnosis of heparin-induced thrombocytopenia is considered definite, probable, possible, and unlikely, respectively. 
다. 39명 환자의 중앙연령은 67세(범위, 51-73세)였고, 남자는 28명, 여자는 11명이었다(Table 3). 본 연구는 서울대학교병 원의 기관생명윤리위원회로부터 연구승인을 받았다 $(\mathrm{H}-1002-$ 056-310).

\section{2. 진성 Heparin-Induced Thrombocytopenia의 진단}

임상 점수체계인 $4 \mathrm{Ts}$ 점수와 Chong 점수를 활용해 $\mathrm{HIT}$ 의 가능성을 예측하였다. Chong 점수는 Chong 점수에서 definite HIT (>7점)와 probable HIT (5-6점)로 판정된 경우 진성 $\mathrm{HIT}$ 가 있다고 진단했다. $4 \mathrm{Ts}$ 점수에서 높은 가능성 (6-8 점)과 중등도 가능성(4-5점)에 대해서 $\mathrm{HIT}$ 의 가능성이 높은 것으로 판단했고, 항체검사결과와 함께 분석하였다.

\section{3. 검사}

1) AcuStar HIT-IgG, total $A b$

HemosIL AcuStar HIT-IgG (PF-4H)와 HemosIL AcuStar HIT-total antibody $(\mathrm{Ab})(\mathrm{PF}-4 \mathrm{H})$ (Instrumentation Laboratory, Bedford, MA, USA)는 자동화된 화학발광면역측정법(chemiluminescent immunoassay)으 로 각각 $\mathrm{PF} 4 /$ polyanion 복합체에 대한 $\operatorname{IgG}$ 항체와 총 항체를 측정하는 검사로 제조사의 지침서에 따라 검사를 시행했다. 두 자동화 검사는 검체를 자성입자가 입혀진 $\mathrm{PF} 4 / \mathrm{polyvinyl}$ sulfonate 복합체와 반응 후 자성을 이용해 자성입자를 분리 하고 세척했다. 항체 결합은 AcuStar HIT-IgG의 특정한 항 인체 IgG 항체 또는 AcuStar HIT-total Ab에 혼합된 2차 항

Table 3. Comparison of clinical and laboratory characteristics between patients with high and moderate probability of HIT and those with low probability of HIT defined by 4Ts score

\begin{tabular}{|c|c|c|c|c|}
\hline \multirow[b]{2}{*}{ Characteristic } & \multirow[b]{2}{*}{ Total $(n=39)$} & \multicolumn{2}{|c|}{ 4Ts score } & \multirow[b]{2}{*}{$P$-value } \\
\hline & & $\begin{array}{l}\text { High \& moderate } \\
\text { probability }(n=15)\end{array}$ & $\begin{array}{l}\text { Low probability } \\
(\mathrm{n}=24)\end{array}$ & \\
\hline Female sex (\%) & $11(28.2)$ & $4(26.7)$ & $7(29.2)$ & 0.866 \\
\hline Platelet count, baseline $\left(\times 10^{9} / \mathrm{L}\right)$ & $136(84-193)$ & $168(117-224)$ & $108(45-163)$ & 0.050 \\
\hline$\%$ Decrease platelet count from baseline & $62.2(3.34-78.3)$ & $71.4(62.0-79.2)$ & $27.7(-9.7-74.9)$ & 0.028 \\
\hline Type of anticoagulation & & & & 0.313 \\
\hline None & $3(7.7)$ & 0 & $3(13.0)$ & \\
\hline UFH only & $19(48.7)$ & $6(40.0)$ & $13(54.2)$ & \\
\hline UFH+LMWH & $6(15.4)$ & $4(26.7)$ & $2(8.3)$ & \\
\hline Cardiac disease & $18(46.2)$ & $8(53.3)$ & $10(41.7)$ & \\
\hline Venous thromboembolism & $4(10.3)$ & $3(20.0)$ & $1(4.2)$ & \\
\hline Vascular surgery & $1(2.6)$ & 0 & $1(4.2)$ & \\
\hline Pneumonia/chronic obstructive pulmonary disease & $2(5.1)$ & 0 & $2(8.3)$ & \\
\hline Others & $14(35.9)$ & $4(26.7)$ & $10(41.7)$ & \\
\hline Chong score & & & & $<0.001$ \\
\hline Unlikely HIT & $16(41.0)$ & $1(6.7)$ & $15(62.5)$ & \\
\hline Possible HIT & $14(35.9)$ & $6(40.0)$ & $8(33.3)$ & \\
\hline Probable HIT & $7(17.9)$ & $6(40.0)$ & $1(4.2)$ & \\
\hline
\end{tabular}

Values are presented as the median (range) for continuous variables or number (\%) for categorical variables, unless otherwise indicated. Abbreviations: HIT, heparin-induced thrombocytopenia; UFH, unfractionated heparin; LMWH, low molecular weight heparin.

${ }^{\star}$ Chi-square test or Fisher's exact test for categorical variables and Man-Whitney $U$ test for continuous variables. 
체(항인체 $\mathrm{IgG} / \mathrm{A} / \mathrm{M}$ )을 이용해 확인하였다. 세척단계와 발광 반응 유도 후 방출된 빛을 ACL AcuStar (Instrumentation Laboratory)의 광학시스템을 이용해 상대적인 광단위 (relative light unit)로 측정하였고, 30 분 안에 임의적인 단위 (arbitrary unit, $\mathrm{U} / \mathrm{mL}$ )로 보고되었다. 두 검사 모두 제조사 지침대로 결과가 $1.00 \mathrm{U} / \mathrm{mL}$ 이상이면 $\mathrm{HIT}$ 항체가 존재한다 고 판단했다.

\section{2) STic EXPERT HIT}

STic Expert HIT (Diagnostica Stago SAS, Asniéres sur Seine, France)는 측면유동면역발색법(lateral flow immunochromatographic assay)으로 PF4/ployanion 복합 체에 대한 $\operatorname{IgG}$ 항체 유무를 확인하는 검사다. 제조사의 지침대 로 $5 \mu \mathrm{L}$ 의 혈장이나 혈청을 검사기구의 검체 투입구에 투입한 다음 완충액 2 방울을 첨가했고, 실온에서 10 분간 반응시킨 다 음 판독했다. 검사자가 육안으로 확인하여 검사선(line-T)이 보이지 않거나 평가 카드의 선보다 연할 경우 음성으로 판독하 고, 검사선과 대조선(line-C)의 결과를 비교하여 검사선의 색 이 대조선과 비슷하거나 더 진할 경우 양성으로 판독했다.

\section{3) PF4 Enhanced}

PF4 Enhanced (Immucor GTI Diagnostics, Waukesha, $\mathrm{WI}, \mathrm{USA}$ )는 정량적인 고체상 효소면역측정법(enzyme linked immunosorbent assay)으로 PF4/polyanion 복합체에 대한 항체를 측정하는 검사로 제조사 지침대로 시행했다. 검체 를 PF4/polyvinyl sulfonate 복합체가 입혀진 microwell에 주 입하고 세척 후 알칼리성 인산분해효소가 입혀진 항인체글로 불린 시약(항-IgG/A/M)을 well에 더한 후 반응시켰다. 결합 하지 않은 항- $\mathrm{IgG} / \mathrm{A} / \mathrm{M}$ 을 세척하고 반응물로 $\mathrm{p}$-nitrophenyl phosphate를 추가했다. 30 분 동안 반응시킨 후 정지용액으 로 반응을 중단 후 분광광도계(spectrophotometer)로 흡광도 (optical density)를 측정하였다.

\section{4. 통계분석}

정성결과는 chi-square 검정 또는 Fisher's exact 검정으로, 정량결과는 Mann-Whitney $U$ 검정으로 비교 분석하였다. 각 항체검사의 결과는 $\mathrm{McNemar}$ 검정으로 비교했고, 연속형 결 과에 대해서는 receiver operating characteristic (ROC) 곡선 분석으로 각각 비교했다. 각 항체검사결과와 $4 \mathrm{Ts}$ 점수를 결합 하기 위하여 로지스틱 회귀분석으로 확률변수라는 새로운 값 을 산정하여 이 값을 $\mathrm{ROC}$ 곡선분석으로 각각 비교했다. 통계 프로그램은 IBM SPSS ver. 19.0 (IBM Co., Armonk, NY,
USA)과 MedCalc ver. 14.8.1 (MedCalc Software, Ostend, Belgium)을 이용하였다. $P<0.05$ 를 통계학적으로 유의한 차 이가 있는 것으로 간주하였다.

\section{결과}

\section{Heparin-Induced Thrombocytopenia 의심 환자군의 임상 양상}

혈소판 수치 초기값의 중앙값은 $136 \times 10^{9} / \mathrm{L}$ (범위, 84-193 $\times 10^{9} / \mathrm{L}$ )이었고, 최하점의 중앙값은 $57 \times 10^{9} / \mathrm{L}$ (범위, 31-82 $\times 10^{9} / \mathrm{L}$ )이었으며, 혈소판 감소비율의 중앙값은 $62.2 \%$ (범위, 3.34-78.3\%)이었다(Table 3). 비분획형헤파린만 사용한 환자 는 19 명 $(48.7 \%)$ 이며, 저분자량헤파린만 사용한 환자는 11 명 $(28.2 \%)$ 이고, 비분획형헤파린과 저분자량헤파린 모두 사용 한 환자는 6 명 $(15.4 \%)$ 이었다. 환자들의 주진단으로는 심장질 환이 18 명(46.2\%)이고, 정맥혈전증은 4명(10.3\%), 혈관 수 술은 1 명 $(2.6 \%)$, 폐렴/만성 폐쇄성 폐질환은 2 명 $(5.1 \%)$, 그 외 질환은 14 명 $(35.9 \%)$ 이었다. 최근에 감염이 있었던 환자는 15 명(38.5\%)이었고, 혈전증이 발생했던 환자는 8 명(20.5\%) 이었다. $4 \mathrm{Ts}$ 점수에서 높은 가능성(6-8점)과 중등도 가능성 (4-5점)이었던 환자는 모두 15 명 (38.5\%)이고, 낮은 가능성 (0-3점)이었던 환자는 24명(61.5\%)이었다. Chong 점수에서 는 definite HIT는 2명(5.1\%), probable HIT는 7명(17.9\%), possible HIT는 14명(35.9\%), unlikely HIT는 16명(41.0\%) 이었다. $4 \mathrm{Ts}$ 점수에서 높거나 중등도 가능성인 환자들에서 기 저치에 비한 혈소판 수치의 감소비율이 높았고, Chong 점수의 등급, 혈전증의 비율이 유의한 차이를 보였다.

\section{2. 항-헤파린/Platelet Factor 4 항체검사들의 Heparin- Induced Thrombocytopenia 진단 성능 평가}

전체 39 명의 환자 중 1 명에서 STic Expert HIT 검사를 검 체부족으로 시행하지 못했다. 전체 환자에서 항체 양성률은 AcuStar HIT-IgG 23.1\% (9/39명), AcuStar HIT-total Ab 48.7\% (19/39명), STic Expert HIT 71.1\% (27/38명), PF4 Enhanced 33.3\% (13/39명)이었다.

Chong 점수에서 5점 이상을 진성 HIT로 가정하고, 각 항체 의 임상성능을 분석하였다. 각 항체검사의 HIT 진단민감도, 진단특이도는 AcuStar HIT-IgG 33.3\%, 80.0\%, AcuStar HIT-total Ab 55.6\%, 53.3\%, STic Expert HIT 100.0\%, $37.9 \%$, PF4 Enhanced 33.3\%, 66.7\%였다(Table 4). 또한 진단정확도는 AcuStar HIT-IgG가 69.2\%로 가장 높았고, PF4 Enhanced 59.0\%, AcuStar HIT-total Ab 53.8\%, STic 
Journal of LABORATORY MEDICINE and QUALITY ASSURANCE

Jae Hyeon Park et al • Performance of Anti-Heparin/PF4 Ab

Table 4. Comparison of diagnostic performance of four different immunoassays and combination with 4Ts score for the diagnosis of heparin-induced thrombocytopenia defined by Chong score

\begin{tabular}{lccccc}
\hline \multicolumn{1}{c}{ Variable } & Sensitivity & Specificity & Positive predictive value & Negative predictive value & Diagnostic accuracy \\
\hline AcuStar HIT-IgG & 33.3 & 80.0 & 33.3 & 80.0 & 69.2 \\
AcuStar HIT-total Ab & 55.6 & 53.3 & 26.3 & 80.0 & 53.8 \\
STic Expert HIT & 100.0 & 37.9 & 33.3 & 100.0 & 52.6 \\
PF4 Enhanced & 33.3 & 66.7 & 23.1 & 76.9 & 51.8 \\
4Ts+AcuStar HIT-IgG & 33.3 & 90.0 & 50.0 & 87.1 & 76.9 \\
4Ts+AcuStar HIT-total Ab & 55.6 & 90.0 & 62.5 & 96.2 & 82.1 \\
4Ts+STic Expert HIT & 88.9 & 86.2 & 66.7 & 81.3 & 86.8 \\
4Ts+PF4 Enhanced & 33.3 & 86.7 & 42.9 & 74.4 \\
\hline
\end{tabular}

Abbreviations: HIT, heparin-induced thrombocytopenia; Ab, antibody.

A

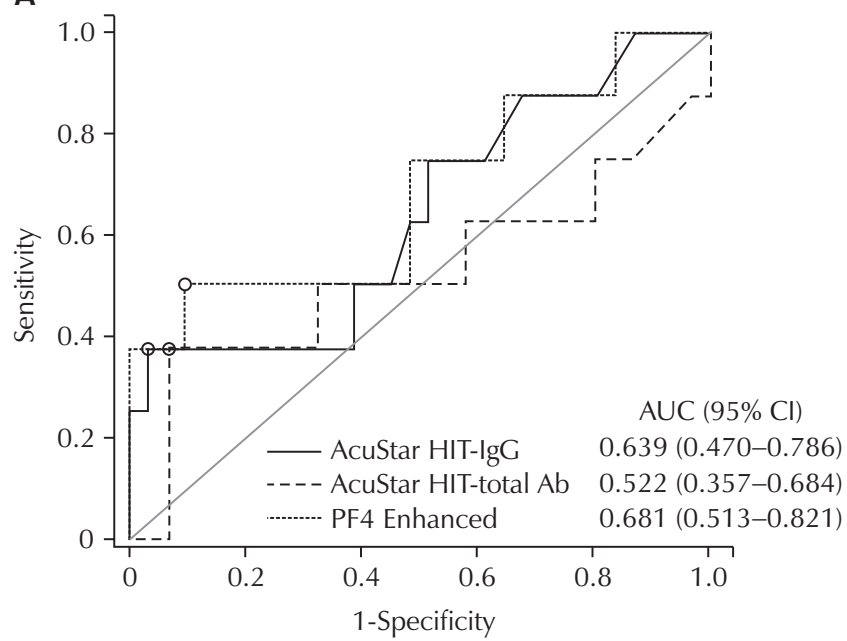

B

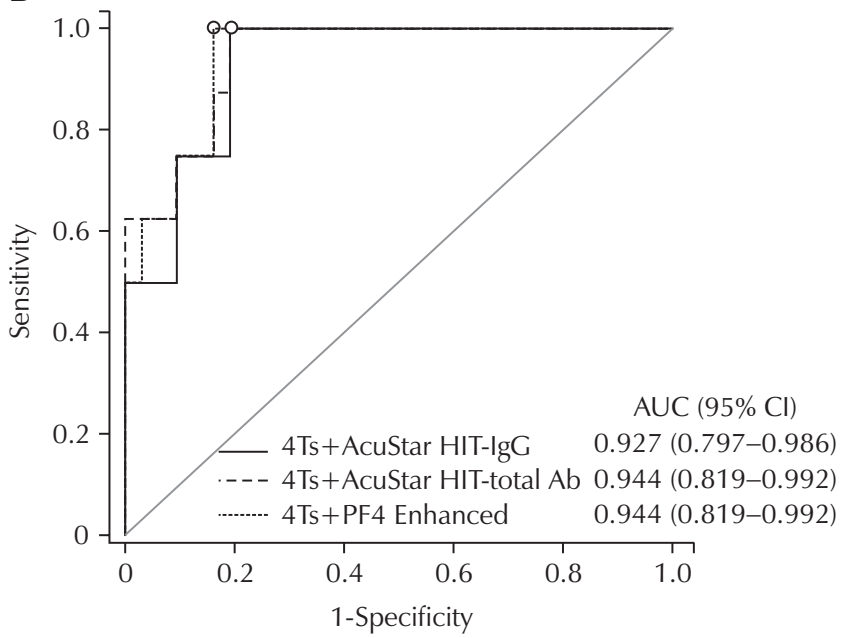

Fig. 1. Comparison of the ROC curves of the three immunoassays with/without 4 Ts scores for prediction of thrombosis. (A) ROC curves of the OD values. (B) ROC curves in combination with OD values and 4Ts scores. Abbreviations: ROC, receiver operating characteristic; OD, optical density; AUC, area under the curve; CI, confidence interval; HIT, heparin-induced thrombocytopaenia; $\mathrm{Ab}$, antibody.

Expert HIT 52.6\%였다.

각 항체검사결과에 임상소견을 포함하여 판단하기 위해 임 상 점수체계인 $4 \mathrm{Ts}$ 점수를 추가하였을 때 진단특이도가 두 드러지게 상승하였다(Table 4). 또한 4Ts 점수를 추가한 경 우 진단정확도는 STic Expert HIT가 86.8\%로 가장 높았고, AcuStar HIT-total Ab 82.1\%, AcuStar HIT-IgG 76.9\%, $\mathrm{PF} 4$ Enhanced $74.4 \%$ 순이었다.

$\mathrm{MeNemar}$ 검사로 네 가지 검사를 각각 비교했을 때 $\mathrm{Acu}-$ Star HIT-IgG 대 AcuStar HIT-total, AcuStar HIT-IgG 대 STic Expert HIT, STic Expert HIT 대 PF4 Enhanced 는 각각 $P$-value가 $0.002,<0.001,0.003$ 으로 유의한 차이
가 있었고, AcuStar HIT-IgG 대 PF4 Enhanced, AcuStar HIT-total 대 STic Expert HIT, AcuStar HIT-total 대 PF4 Enhanced는 유의한 차이가 관찰되지 않았다. 네 가지 검사의 불일치 정도를 비교했을 때, STic Expert HIT만 양성인 환자 가 10명(26.3\%)이었고, STic Expert HIT와 AcuStar HITtotal $\mathrm{Ab}$ 만 양성인 환자가 7명(18.4\%)이었다.

\section{3. 항-헤파린/Platelet Factor 4 항체 검사들의 혈전증 발생의 예측력 비교}

혈전증 발생의 예측력을 비교하기 위해 세 항체검사결과 로 ROC 곡선을 그렸을 때 area under the curve (AUC)는 


\title{
Journal of LABORATORY MEDICINE and QUALITY ASSURANCE
}

\author{
Jae Hyeon Park et al • Performance of Anti-Heparin/PF4 Ab
}

AcuStar HIT-IgG 0.639 (95\% confidence interval [CI], 0.470 to 0.786), AcuStar HIT-total Ab 0.522 (95\% CI, 0.357 to 0.684 ), PF4 Enhanced 0.681 (95\% CI, 0.513 to 0.821)이었다(Fig. 1A). 세 항체검사의 AUC 값 간의 유의한 차이는 관찰되지 않았다.

세 항체검사의 결과에 $4 \mathrm{Ts}$ 점수를 추가하였을 때 AcuStar HIT-IgG의 AUC는 0.927 (95\% CI, 0.797 to 0.986)로 현저 히 증가하였다(Fig. $1 \mathrm{~B}$ ). 각 항체검사결과에 $4 \mathrm{Ts}$ 점수를 추 가한 경우 AUC 값의 유의한 상승이 있었다(AcuStar HITIgG vs. 4Ts + AcuStar HIT-IgG, P=0.008; AcuStar HITtotal Ab vs. 4Ts + AcuStar HIT-total Ab, $P=0.007$; PF4 Enhanced vs. 4Ts + PF4 Enhanced, $P=0.019$ ).

\section{고찰}

$\mathrm{HIT}$ 진단에서 면역학적인 항-헤파린/PF4 항체검사의 민감 도는 매우 우수하다고 보고되어있다[2,4,7-13]. 그러나 항-헤 파린/PF4 항체검사만으로는 $\mathrm{PF} 4$ 에 대한 비병원성의 항체나 항인지질 항체를 감별해낼 수 없기에 위양성이 많아 HIT를 과 진단하게 되며, 이를 보완하기 위해 IgG에 특이적인 항체를 검 출하거나 흡광도의 기준치를 높이는 방법이 있으나 여전히 위 양성은 존재하고 위음성이 발생할 위험이 있다[7]. 임상적인 지표로는 4Ts 점수와 Chong 점수 등이 있으며, $4 \mathrm{Ts}$ 점수가 사 용하기 간단하고 음성예측도가 우수하여 널리 사용되고 있다. 4Ts 점수에서 높은 가능성 (6-8)과 중등도 가능성(4-5)인 환자 에서 항체 검사를 시행하고, 흡광도 결과가 높으면 헤파린을 중단하고, HIT 치료를 시작하는 방법도 제시되었다[2].

$\mathrm{HIT}$ 항체검사의 성능을 평가한 보고에 따르면 AcuStar $\mathrm{HIT}-\mathrm{IgG}$ 의 진단민감도는 96.2-100.0\%, 진단특이도는 85.0-96.5\%, AcuStar HIT-total Ab의 진단민감도는 98.1$100.0 \%$, 진단특이도는 73.0-91.2\%로 보고되었다[4,9,11,12]. STic Expert HIT의 진단민감도는 97.5-100.0\%, 진단특이도 는 82.2-93.0\%로 보고되었고[10,13], PF4 Enhanced는 진단 민감도 93-100\%, 진단특이도 65-93\%로 보고되었다[8,10].

본 연구에서는 4 가지 항체검사를 동시에 비교 평가하였고, 여러 상품화된 시약을 함께 비교한 보고한 경우는 거의 없었 다. 기존 보고에서 이들 항체들의 진단민감도가 비교적 우수하 였으나[4,8-13], 본 결과에서는 진단민감도가 비교적 낮게 관 찰되었다. 이는 진성 HIT를 정의하는데 기준이 다르기 때문으 로 생각된다. 본 연구에서는 Chong 점수의 definite HIT (>7 점)와 probable HIT (5-6점)로 진성 HIT를 정의한 반면, 다른 연구들에서는 기능검사에서 양성인 경우를 진성 HIT로 정의
하였다. 따라서 Chong 점수로만 진성 HIT를 판단하였으므로 기능검사 음성인 환자가 포함되어 진단민감도가 낮아졌을 가 능성이 있다.

본 연구에서 STic Expert HIT는 진단민감도가 $100.0 \%$ 로 우수했으나 진단특이도가 $37.9 \%$ 로 낮았다. AcuStar HITIgG와 AcuStar HIT-total Ab를 비교했을 때, IgG만 특이 적으로 검출한 것이 진단특이도는 더 우수했으나 $(80.0 \%$ vs. $53.3 \%$ ) 민감도는 더 떨어지는 것으로 관찰되었다(33.3\% vs. $55.6 \%) . \mathrm{PF} 4$ Enhanced의 경우에는 진단민감도는 AcuStar $\mathrm{HIT}-\mathrm{IgG}$ 와 동일했고, 특이도는 AcuStar HIT-IgG와 AcuStar HIT-total Ab 사이의 결과를 나타냈다. $4 \mathrm{Ts}$ 점수와 함께 항체검사를 해석했을 때 진단특이도와 양성예측도가 개 선되었고, 다른 검사에서는 진단민감도의 변화가 없으나 STic Expert HIT의 경우에는 민감도가 다소 감소하는 것이 관찰되 었다. 세 가지 항체검사의 혈전증 예측도를 분석했을 때 $\mathrm{ROC}$ 곡선의 AUC는 PF4 Enhanced가 0.681로 다른 두 검사에 비 해서 높았으나 통계적으로 유의한 차이를 보이지 않았다. 또한 항체검사결과에 $4 \mathrm{Ts}$ 점수를 추가하였을 때 혈전증 예측력이 현저히 상승하는 것을 관찰하였다.

STic Expert HIT의 경우 진단특이도가 낮았는데, STic Expert HIT결과만 양성인 경우가 전체의 26.3\% (10/38건)이 었다. 이는 자동화된 검사와는 달리 STic Expert HIT의 경우 검사자가 육안으로 검사선과 대조선을 비교하여 검사선의 색 이 대조선과 비슷하거나 더 진할 경우 양성으로 판독하도록 되 어 있어 검사자에 따라 양성률이 다를 수 있어 검사판독에 주 의를 요한다[13].

HIT는 혈소판 활성을 증가시키는 항체의 존재를 확인하여 야 하므로 기능검사인 세로토닌분비검사와 헤파린유도혈소판 활성검사가 중요하다. 그러나 현실적으로 기능검사는 표준화 된 검사실에서만 시행되고 있고, 국내에서는 시행하지 못하고 있다. 본 연구에서 기능검사를 시행할 수 없어서 진성 HIT에 대한 정의를 Chong 점수로 판단하여 HIT 환자군에 기능검사 음성환자가 일부 포함되었을 가능성이 있다. 따라서 항체의 진 단민감도가 낮게 평가되고, 진단특이도가 상대적으로 높게 평 가되었다. 향후 HIT 기능검사가 임상검사실에서 용이하게 수 행될 수 있는 상품화된 검사시약이 개발되기를 기대한다.

결론적으로 항-헤파린/PF4 항체에 대한 4가지 검사를 비교 했을 때 STic Expert HIT는 진단민감도가 높으나 진단특이도 가 낮았고, 나머지 항-헤파린/PF4 항체검사들 간의 성능은 유 사하였다. 각 항체검사를 $4 \mathrm{Ts}$ 와 함께 해석했을 때 진단특이도 가 현저히 상승한 결과를 보였다는 점은 향후 HIT 진단에 검 사결과와 임상점수체계가 결합하여 유용하게 사용될 수 있을 


\title{
Journal of LABORATORY MEDICINE and QUALITY ASSURANCE
}

\author{
Jae Hyeon Park et al • Performance of Anti-Heparin/PF4 Ab
}

것으로 생각된다.

\section{REFERENCES}

1. Warkentin TE. HIT paradigms and paradoxes. J Thromb Haemost 2011;9 Suppl 1:105-17.

2. Cuker A. Clinical and laboratory diagnosis of heparininduced thrombocytopenia: an integrated approach. Semin Thromb Hemost 2014;40:106-14.

3. Warkentin TE, Greinacher A, Gruel Y, Aster RH, Chong BH; scientific and standardization committee of the international society on thrombosis and haemostasis. Laboratory testing for heparin-induced thrombocytopenia: a conceptual framework and implications for diagnosis. J Thromb Haemost 2011;9:2498-500.

4. Van Hoecke F, Devreese K. Evaluation of two new automated chemiluminescent assays (HemosIL ${ }^{\circledR}$ AcuStar HIT-IgG and HemosIL ${ }^{\circledR}$ AcuStar HIT-Ab) for the detection of heparin-induced antibodies in the diagnosis of heparin-induced thrombocytopenia. Int J Lab Hematol 2012;34:410-6.

5. Warkentin TE, Heddle NM. Laboratory diagnosis of immune heparin-induced thrombocytopenia. Curr Hematol Rep 2003;2:148-57.

6. Chong BH, Chong JJ. Heparin-induced thrombocytopenia. Expert Rev Cardiovasc Ther 2004;2:547-59.

7. Cuker A. Heparin-induced thrombocytopenia (HIT) in 2011: an epidemic of overdiagnosis. Thromb Haemost 2011;106:993-4.
8. Shaheed G, Malkovska V, Mendoza J, Patel M, Rees J, Wesley R, et al. PF4 ENHANCED assay for the diagnosis of heparin-induced thrombocytopenia in complex medical and surgical patients. Crit Care Med 2007;35:1691-5.

9. Legnani C, Cini M, Pili C, Boggian O, Frascaro M, Palareti G. Evaluation of a new automated panel of assays for the detection of anti-PF4/heparin antibodies in patients suspected of having heparin-induced thrombocytopenia. Thromb Haemost 2010;104:402-9.

10. Sachs UJ, von Hesberg J, Santoso S, Bein G, Bakchoul T. Evaluation of a new nanoparticle-based lateral-flow immunoassay for the exclusion of heparin-induced thrombocytopenia (HIT). Thromb Haemost 2011; 106:1197-202.

11. Althaus K, Hron G, Strobel U, Abbate R, Rogolino A, Davidson S, et al. Evaluation of automated immunoassays in the diagnosis of heparin induced thrombocytopenia. Thromb Res 2013;131:e85-90.

12. Jourdy Y, Nougier C, Rugeri L, Bordet JC, Sobas F, Negrier C. Prospective evaluation of automatized PF4/ heparin immunoassays HemosIL HIT-ab (PF4-H) for the diagnosis of heparin-induced thrombocytopenia. Int J Lab Hematol 2015;37:244-52.

13. Leroux D, Hezard N, Lebreton A, Bauters A, Suchon $\mathrm{P}$, de Maistre E, et al. Prospective evaluation of a rapid nanoparticle-based lateral flow immunoassay (STic Expert $\left({ }^{\circledR}\right)$ HIT) for the diagnosis of heparin-induced thrombocytopenia. Br J Haematol 2014;166:774-82. 
Journal of LABORATORY MEDICINE and QUALITY ASSURANCE

Jae Hyeon Park et al • Performance of Anti-Heparin/PF4 Ab

헤파린유도혈소판감소증 진단을 위한 항-헤파린/Platelet Factor 4 항체검사 평가

박재현 • 김지은 - 유현주・구자윤 • 한규섭・김현경

서울대학교 의과대학 진단검사의학교실

배경: 헤파린유도혈소판감소증(heparin-induced thrombocytopenia, HIT)은 헤파린과 platelet factor 4 (PF4)의 복합체에 대한 대한 자가항체에 의해서 발생하며 혈전증을 일으킬 수 있는 심각한 합병증이다. 본 연구에서는 HIT 진단을 위해 사용할 수 있는 상품화된 항-헤파린/PF4 항체 시약들의 진단성능을 평가하였다.

방법: HIT가 의심되는 39명의 환자에서 4종류의 항-헤파린/PF4 항체 시약을 이용하여 제조사의 지침에 따라 검사하였다: HemosIL AcuStar HIT-IgG, HemosIL AcuStar HIT-total antibody (Ab) (Instrumentation Laboratory, USA), STic Expert HIT (Diagnostica Stago, France), PF4 Enhanced (Immucor GTI Diagnostics, USA). HIT 진단은 기존의 임상 점수체계인 Chong 점수 5 점 이상으로 설정하였다.

결과: HIT 진단에 대한 각 검사의 민감도, 특이도는 각각 AcuStar HIT-IgG 33.3\%, 80.0\%, AcuStar HIT-total Ab 55.6\%, 53.3\%, STic Expert HIT 100.0\%, 37.9\%, PF4 Enhanced 33.3\%, 66.7\% 였고, 각 결과에 $4 \mathrm{Ts}$ 를 진단기준으로 추가했을 때 특이도가 현저히 상승하였다. 혈전증 발생가능성 의 area under the curves (AUC)는 AcuStar HIT-IgG 0.639, AcuStar HIT-total Ab 0.522, PF4 Enhanced 0.6810있고, 각 항체결과와 4Ts를 함께 분석한 결과, AUC가 4Ts+AcuStar HIT-lgG는 0.927, 4Ts+AcuStar HIT-total Ab와 4Ts+PF4 Enhanced는 0.944로 상승하였다.

결론: STic Expert HIT은 민감도가 높으나 특이도가 낮았고, 나머지 항-헤파린/PF4 항체검사들 간 의 성능은 유사하였다. 각 항체검사를 $4 \mathrm{Ts}$ 와 함께 해석했을 때 특이도가 현저히 상승했다. 혈전증 예 측에 대한 각 면역검사의 진단성능은 차이가 없었고, 임상 점수체계를 함께 고려했을 때 진단성능이 개선될 것이다.

(J Lab Med Qual Assur 2015;37:84-91) 